and south of the equator. The marked minima in $S^{\prime}$ in either June or July from 1958 to 1962 result from a latitude variation in density and the perigee of $1958 \propto$ being at a maximum distance south of the sub-solar point in these months. A minimum should also be expected in $S^{\prime}$ in December or January. Such a minimum is indicated in 1961 and 1962; however, it is not apparent in 1958-1960. This minimum should not be so great as the June or July minimum because the Earth intercepts less extreme ultra-violet radiation during these latter months due to the greater Earth-Sun distance. The magnitude of the June or July minima cannot be completely explained on the basis of the seasonal curves in Fig. 4, but it is expected that curves for the individual months containing the solstices would indicate much greater latitudinal density gradients. The analysis of the data was unavoidably based on 3-month seasons because of the limited amount of $S^{\prime}$ data. The latitudinal density gradients for the individual months of a given season will differ from the 3-month curves, especially near the solstices. If a marked latitude density gradient does exist in the winter hemisphere near the solstices, as indicated by this analysis, then it should be reflected also in the $P$ values for satellites other than $1958 \propto$ as their perigee latitudes change north and south of the equator. Other satellites do show the existence of a marked latitudinal density gradient, especially near the time of the solstices ${ }^{15}$. Thus, there seems to be little doubt that perigee latitude and the latitude of the sub-solar point are factors that must be taken into account in any analysis of the $P$ variations, particularly near the solstices.

This work was supported by the Lockheed Independent Research Programme.

${ }^{1}$ Groves, G. V., Proc. Roy. Soc., A, 263, 212 (1961).

2 Paetzold, H. K, and Zschörner, H., Space Res., 2, 958 (1961).

${ }^{3}$ Priester, W., Martin, H. A., and Kramp, K., Nature, 188, 202 (1960).

- May, R. R., Planetary Space Sci.,12, 1179 (1964).

${ }^{5}$ Anderson, A. D., J. Atmos, Sci., 21, 1 (1964).

${ }^{6}$ Jacchia, L. G., and Slowey, J., Accurate Drag Determinations for Eight Artificial Satellites. Smith. Inst. Astrophys. Obs. Spec. Rep., 100, 55 (1962) 7 Izsak, I. G., Satellite Orbital Data. Smith. Inst, Astrophys. Obs. Spec. Rep. 86 and $93,10(1962)$.

${ }^{8}$ Izsak, I. G., Satellite Orbital Data. Smith. Inst. Astrophys. Obs. Spec. Rep. $113,117,120$, and 126,7 (1963).

Jachia, L. G., and Slowey, J., Short-Period Oscillations in the Drag of Satellite 1958 a. Smith. Inst. Astrophys. Obs. Spec. Rep., 77, 1 (1961).

${ }^{10}$ Jacchia, L. G., Space Res., 2, 747 (1961).

${ }^{11}$ Dessler, A. J., J. Geophys. Res., 64, 397 (1959).

12 Jacchia, I. G., and Slowey, J., J. Geophys. Res., 69, 905 (1964).

${ }^{13}$ Anderson, A. D., The Latitude and Seasonal Variation of Density from 200 to $800 \mathrm{~km}$ (Lockheed Missiles and Space Company Document No. 6-75-65-6, 1965).

${ }^{14}$ King, J. W, and Kohl, H., Nature, 206, 699 (1965).

15 Anderson, A. D., A Simple Explanation for the Semi-Annual Effect Appearing in Satellite Orbital Decay Data (Lockheed Missiles and Space Company Document No. 6-75-65-43, 1965).

\title{
OBITUARIES
}

\section{Dr. F. H. Pollard}

Frederick Henry Pollard was born on June 6, 1907 , in Swindon. After leaving school, he entered the University of Bristol in 1923, and took a bachelor's degree in 1927 , reading chemistry as special subject. After taking a Diploma in Education in 1928, also at Bristol, he was appointed head of the Science Department at Thornbury Grammar School, Gloucestershire, from 1929 to 1937. In 1937 he moved to Hanley High School, where he proceeded to teach for a further 5 years. While at Thornbury Grammar School, Pollard was persuaded by Prof. W. E. Garner to work part-time for his Ph.D. The research work he carried out was on the infra-red spectra of carbon mon oxide flames and he was awarded a Ph.D. in 1935. This interest, which he developed, he maintained until his untimely death.

In 1941, Pollard accepted the post of lecturer in inorganic chemistry at Bristol and was appointed senior lecturer in 1951 , reader in 1954 , and finally awarded the degree of D.Sc. in 1959. During the Second World War he worked with Dr. W. J. Dunning and others on the explosive $R D X$. Among the reactions he investigated were those between the oxides of nitrogen and low-molecular weight organic compounds; for example, formaldehyde and acetic acid. This interest, together with his responsibilities to the Department of Chemistry at Bristol, led him into the field of inorganic chemistry research. However, Pollard soon became convinced that more powerful methods of analysis would greatly increase the scope of inorganic chemistry. He began his research career relatively late in life, but, as is internationally recognized, he published an impressive collection of nearly one hundred scientific papers. The papers he published can be grouped under five headings: (a) inorganic chromatography; $(b)$ gas chromatography studies; (c) thermal decomposition of organic nitrates; $(d)$ carbides, silicides, nitrides and their reactions; and (e) co-ordination chemistry of new analytical reagents. Pollard began his work on inorganic chromatography in order to investigate how far paper and ion-exchange chromatography could be applied to the analysis of inorganic compounds with two ultimate aims: the development of a complete scheme of qualitative analysis; and the application of quantitative methods to the investigation of inorganic reaction mechanisms. At the time of his death, he was engaged on the establishment of a course in advanced analytical chemistry leading to the degree of M.Sc.

Pollard energetically shouldered the major burden of organizing the teaching of inorganic chemistry at Bristol, and was responsible for building up a vigorous school of teaching and research. It can be said that the foundation of inorganic chemistry at Bristol was his chosen life's work.

He took an active part in many University matters and had a knowledge and experience of schools and especially sixth-form work which was of great value in the matters of entrance requirements and student selection. Pollard was a member of the committee responsible for policy decisions on all building aspects of the new School of Chemistry, with the special duty of co-ordinating the scheme. He also found time to take an active part in the local and central activities of the Chemical Society, and the Society for Analytical Chemistry, serving on the councils of both bodies. In addition to this, he never severed his links with the teaching profession, in that he organized and lectured at conferences for teachers. In committee, Pollard's contributions, although often out. spoken, were given with sincerity and deep feeling, in order that the correct choice might be made. He loved playing 'devil's advocate', a quality which often caused him trouble, being so easily misunderstood.

In spite of all these calls on his time, Pollard always took a very keen interest in the welfare of students, and anyone was welcome to ask his advice on problems of a personal nature. His quip to all of us was, "My door is always open". Characteristic of him was the effort, time and thought he gave to the development of student interchanges, especially between the Department of Chemistry, Bristol, and the Anorganische Institut, Technischen Hochschule, Brunswick, an association which developed from the lectures he gave in Germany in 1953 under the auspices of the Rockefeller Interchange Scheme.

His sudden death at the age of fifty-eight left his career sadly incomplete. During his life he never spared himself to serve his own generation, together with those generations in his charge which made up the University, to the best of his ability. Those of us who were his students are 
deeply grateful. Although he listened with sympathy he could be a task-master-to all of us he was our 'father figure'. In the School of Chemistry at Bristol he will long be missed.

G. Nrokless

\section{Dr. Allen B. Du Mont}

Dr. Aluen B. Du Mont, the television pioneer of Cedar Grove, New Jersey, died on November 14, 1965, at the age of sixty-four. $\mathrm{He}$ was best known for his work in perfecting the cathode-ray tube.

Dr. Du Mont was born in Brooklyn, New York, on January 29, 1901, and he became a ship's wireless operator at an early age. He received his degree in electrical engineering from the Rensselaer Polytechnic Institute, Troy, New York, in 1924, and afterwards received honorary degreos from the Rensselaer Polytechnic Institute, the Brooklyn Polytechnic Institute, Fairleigh Dickinson University, Now York University, and Montclair State College.

At the Westinghouse factory in Bloomfield, New Jersey, Dr. Du Mont worked on the development of high-speed manufacturing and test equipment for radio tubes. Later, as chief engineer of the De Forest Radio Company, of Passaic, New Jersey, he worked closely with Lee De Forest. In 1928 they established the first synchronized sight and sound television station $W 2 X C D$, using the Nipkow disk mechanical scanner at both the camera and receiver.

Recognizing the limitations of a mechanical television system, he then started his own company in 1931, later known as Allen B. Du Mont Laboratories, Inc. Dr. Du Mont afterwards expanded the company to produce a variety of cathode-ray tubes, the first commercially sold television receivers, television broadcast transmitters and studio equipment and an extensive range of scientific apparatus. He started the Du Mont Network with Station $W A B D$ before the second World War and later linked it with the companion Station $W^{\prime} T G$ in Washington, D.C. From 1934 until the merger in 1960 with Fairchild Camera and Instrument Corporation, Dr. Du Mont served as director, president or chairman of the board of the Allen Du Mont Laboratories, Ine.
During the 'thirties, Dr. Du Mont worked on the development of radar systems and cathode-ray displays for both the Signal Corps and the Navy. His company contributed greatly in these fields during the Second World War and also to the Loran and Manhattan Projects, and later to nuclear propulsion instrumentation.

Dr. Du Mont served on the National Television System Committee, contributing to the formulation of broadcast standards for both monochrome and colour television. He was United States delegate to the International Radio Consultative Committee for consideration of international colour television standards. $\mathrm{He}$ collaborated extensively with the Federal Communications Commission in matters pertaining to the allocation of very high and ultra-high frequency television channels.

In 1943 he became the first president of the Television Broadcasters Association, which later combined with the National Association of Broadcasters for both radio and television.

Through the Allen B. Du Mont Foundation he took part in the establishment of Educational Television in co-operation with the Montclair State College in New Jersey and served on the Now Jersey Commission for Educational Television. The Foundation also participated in and financed research in medical electronics.

Among his many awards, Dr. Du Mont received the Marconi Award of Achievement, the Horatio Alger Award, and he was made Chevalier de la Légion d'Honneur. In 1927 he was awarded the Westinghouse Award for Most Outstanding Accomplishment, in 1943 the American Television Society Award for Advancement of Commercial Television, and in 1944 the Television Broadcasters Association Award for the development of the cathoderay tube.

Dr. Du Mont was one of the Public Governors of the American Stock Exchange and was vice-chairman of the Board of Trustees of Rensselaer Polytechnic Institute.

As an enthusiast for power boats, Dr. Du Mont won many awards for navigational accuracy in predicted log racing. With his boats, Hurricane $I I$ and Hurricane $I I I$, he did much to discover and interpret the multi-path and propagation effects of both television and radar signals. Thomas T. Goldsmith, JUn.

\section{NEWS and VIEWS}

Steacie Prize : Prof. N. Bartlett and Prof. J. C. Polanyi

Prof. Neil Bartlets, of the Department of Chemistry, University of British Columbia, and Prof. J. C. Polanyi, of the Department of Chemistry, University of Toronto, will share the 1965 Steacie Prizo. The Prize consists of the income from the E. W. R. Steacie Memorial Fund to which colleagues and friends of the late president of the National Research Council contributed. It is awarded annually for outstanding work done in the natural sciences by younger people. Prof. Bartlett is cited for the first preparation of a chemical compound of a noble gas (Proc. Chem. Soc., 218; 1962). The compound, $\mathrm{XePtF}{ }_{6}$, was prepared by the reaction of xenon with platinum hexafluoride. This startling experiment ovolved logically from work on the fluorination of platinum and platinum compounds that Prof. Bartlott had been doing with D. H. Lohmann. The result immediately stimulated a flurry of experiments in other countries and soon a number of compounds of xenon and krypton had been prepared. The ramifications will not soon be oxhausted. Prof. Polanyi was the first to observe infra-red chemiluminescence (Cashion, J. K., and Polanyi, J. C., J. Chem. Phys., 29, 455; 1958), the occurrence of which he had predicted theoretically two years previously. The experimental techniques that he evolved have now been refined, and a wide range of atomic and molecular excitations caused by chemical reactions are being studied in Toronto and elsewhere. Five years ago, he published a proposal for a chemical laser (J.Chem. Phys., 34, 347; 1961) and it has recently been shown to be practical. Both Prof. Bartlett and Prof. Polanyi are graduates of British universities. The former received a Ph.D. in 1958 from the University of Durham and the latter a Ph.D. in 1952 and a D.Se. in 1964 from the University of Manchester.

\section{Principal of the University of Stirling:}

Prof. T. L. Cottrell

Prof. T. L. Cottrell, professor of chemistry in the University of Edinburgh, will take up full-time duties as principal of the new University of Stirling in August. Prof. Cottrell graduated with honours in chemistry at the University of Edinburgh in 1943, and joined the Rescarch Department of the Explosives Division of Imperial Chemical Industries, Ltd., at Ardeer. After working in the Physical Chemistry Laboratory at Oxford, he returned to Imperial Chemical Industries (Nobel Division) and became head of the Physical Chemistry Research Section in 1950. He was awarded the Meldola Medal of the Royal Institute of Chemistry in 1952. At the time of his appointment to the chair of chemistry in 